\title{
The fine structure of the infundibulum-magnum junctional area of the quail oviduct
}

\author{
Takashi Makita and Sukechika KIwaKI \\ (Veterinary Anatomy, Faculty of Agriculture, Yamaguchi University) \\ (Received for Publication on August 15, 1967)
}

The infundibulum of the avian oviduct is subdivided into the posterior part (funnel) and the anterior part (narrow tube). Though some investigators mentioned the difference of their function, the changes in appearance of the inner surface did not always agree with that of the outer shape of the tube just as was the case with the isthmus-uterus junction. The junctional area under consideration, therefore, was restricted to the most distal part of the narrow tube. In the previous paper, we described the fine struture of the infundibulum of the quail oviduct (MAKITA and KIWAKI ${ }^{5)}$ ) and that of the magnum is also in preparation. Both in hen (MAKITA and NISHIDA) and quail, the ciliated cells showed minor varieties throughout the oviduct while the non-ciliated cells had the regional and functional differences. The nonciliated cell in the infundibulum, for example, was not the goblet cell such as those found in the magnum. The junctional area, however, represented a transitional nature between infundibulum and magnum in histological aspects without any conspicuous demarcation and it might be a cause of confusion among the investigators. To permit the more clear comparison among the subdivisions, the present investigation was undertaken in search of the specificity of this junction.

\section{Materials and Methods}

Three laying birds and two non-laying birds were used in this investigation. The tissues were fixed in the cold $1 \%$ osmium tetraoxide about for one hour. Some were also prefixed in the cold $4 \%$ glutaraldehyde buffered with sodium cacodilate. Dehydrated with the series of graded ethanols, they were embedded in Epon 812 followed by the sectioning on a LKB ultrotome. Sections post-stained with uranyl acetate and/or lead citrate solution were viewed with a JEM-5 electron microscope.

\section{Observations}

Infundibulum-Magnum area ranged from $1.0 \mathrm{~cm}$ to $1.5 \mathrm{~cm}$ in length and was mostly situated in the distal end of the narrow tube. The diameter of the tube was less than $0.5 \mathrm{~cm}$ and unlikely to change even when the bird was not laying. The most characteristic feature of the area to distinguish it from the rest of the infundibulum was the slight change of the colour on its inner surface which increased the whitish colour due to that of the magnum. The inner surface was covered with the velvetty projections which were not arranged yet in the longitudinal folds as much as in the magnum and isthmus. Light 
Infundibulum-Magnum junction of quail odiduct

microscopically, some infundibulum glands, though small in number, were in the depth of the mucosa. They were often mingled with the magnum glands as hen were. Electron microscopically the ciliated cells were similar to those of the funnel in every respects of the cilia and cell organelles (Fig. 1). On the other hand, the non-ciliated cells of this area showed somevariations which could be detected with light microscopy. One of those specific features of the non-ciliated cells was the globules which contained some dense particles or and the filaments in the light ground substance. The globules and their contents were more remarkable in the basal area of the cell (Figs. 2, 3,4.). Considering the vacuoles found in the infundibulum and the filaments contained in secretions specific to the magnum gland, those globules may be a transitional form of the secretions.

The another type of the non-ciliated cell was a sort of goblet cell which was not found in the rest of the infundibulum. The secretion of this goblet cell, however, contained fine grains and had not any network pattern that was characteristic to the goblet cell in the magnum. The supranuclear region of the goblet cell was almost occupied with the secretions (Fig. 5) and some mitochondria, Golgi complex and short endoplasmic reticulum (ER) were distributed in the space among them (Fig. 6).

Except the infundibulum gland of which cells contained the medium sized dense granules, no specific gland to this area had been found but the considerable number of the magnum glands were already here (Fig. 7).

The cell of the muscular layer in the area represented the remarkable evagination of their cell walls (Fig. 8). Collagenous fibers and vacuoles with light substance were also seen among among them.

\section{Discussion}

RichardSON" had named the narrow tube as "the chalaziferous region" but the resection of about $80 \%$ of that part resulted no significant effect on the formation of chalazae of the egg (Burmester and $\mathrm{CARD}^{2}$ )). Our preliminary experiment on the quail oviduct also indicated it might be so. Even in the field of electron microscopy, Artken and Johnstow ${ }^{1}$ ) who described two types of true gland in the narrow tube of the hen were of the opinion that "the microvilli of the infundibulum gland cell distinguished these from those of the magnum from whicn microvilli were absent" but contrary to this opinion the gland cells in the magnum of the hen had microvilli (Makita and NishiDA)). The infundibulum glands were small in number through the whole narrow tube and another type of gland was not confirmed in the transitional area though the magnum gland itself could be seen here.

Despite of those facts mentioned above, the specifity of this area is still to be established. Our findings though less remarkable than those with the naked eye as yet, might have the signigicance in this connection.

Firstly, we mentioned the transitional nature of the globules found in some of the nonciliated cells. Those globules had not been in the rest of the infundibulum. However, at least two problems should be referred concerning to the inner matrices of the globules. One is that there still remains the probability of a fixation artifact because the dark particles as well as the filaments in the globules are less remarkable in the case of the materials prefixed with gultaraldehyde. Another is that it is not in the magnum epithelium but in the magnum gland that we previously found the filaments containing secretion. Containing the epithelial 


\section{MAKITA $\cdot$ KIWAKI}

cells the similar filaments in their globules may suggest the correlation of the epithelium with the true gland in the magnum, though we did not confirm it yet.

Secondly, the goblet cell was specific to the area and had not seen in the rest of the infundibulum. The secretion of the goblet cell of the area, however, was not alike those in the goblet cells in magnum, the junctional area between magnum and isthmus, and vagina. As stated already, the secretion in the goblet cells of those subdivisions showed an irregulary shaped network pattern which had a dense core. Judging from the micrographs of the goblet cells, secretions have close relationship with ER though the Golgi complex has been considered to play a more direct role in the formation of secretion of goblet cells (FREEMAN ${ }^{3)}$ ).

These specificities of the junctional area support the opinion that the infundibulum also secrets the protein somewhat different from those secreted in the magnum (ScotT and HUANG $\left.{ }^{7)}\right)$.

\section{Summary}

Infundibulum-Magnum junctional area of the quail oviduct was observed electromicroscopically. The most salient feature of the area was the globules in the non-ciliated cells in which some dense particles and filamentous elements were found. They might be a transitional form between the specific vacuoles of infundibulum and the filaments containing secretions in the magnum gland. Another specific feature was a kind of goblet cell that had not been seen in the rest of infundibulum. The secretions of the goblet cell contained fine grains but had no irregular pattern of network as was the case with that of magnum.

Tubular gland specific to this region had not been found though both the infundibulum gland and the magnum gland were seen.

In the muscular layer, the remarkable evagination of the cell walls and filaments around the nucleus were noticed. Many vacuoles with the substance of low electron density were distributed among colagenous fibers in the serous coat.

\section{Acknowledgements}

The authors are deeply indebted to Dr. S. Nishiba and Dr. K. Mochizuki for their constant encouragement and advice. They would also like to thank Mr. KuRasurma for the provision .of the quails.

\section{References}

1) Aitken, R.N.C. and H.S. Johnston (1963) J. Anat., Lond., 97: 87-99.

2) Burmester, B.R. and L.E. Card (1939) Poult. Sci., 18: 138-145.

3) Freeman, J.A. (1966) Anat. Rec., 154: 121-148.

4) Makita, T. and S. Nishida (1966) Electron Microscopy 1966 Vol. II: 777-778. Maruzen, Tokyo.

5) Makita, T. and S. Kiwaki (1968) Jap. J. Zootech. Sci., 39: 246-254.

6) Richardson, K.C. (1935) Phil. Trans. B., 225: 149-196.

7) Scotr, H.M. and W. HANG (1941) Poult. Sci., 20: 402-405. 


\title{
鶉の卵管の漏斗部之膨大部との移行部の微細構造
}

\author{
牧田登之・木脇祐順 \\ (山口大学農学部)
}

産畉中の竬 3 羽と休産中の鵫 2 羽の眀管を用いて，漏 斗部と䁗大部 (蛋白分泌部) との移行部電顕で観察し， 光影によって明らかにされてなかった特徴を認めた。

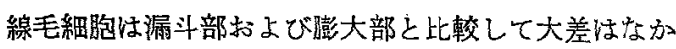
ったが，非線毛細胞では特異な顆粒がみられた．この顆 粒㑑道径 $0.5 \mu$ 前後のものが多く，一様汇高い電子密度 を示するの，明るい物質の中に暗い部分が散在するる の，蛋白分泌腺の顆粒内に多られる様な微細線維状の物 質を内包するものおよびてれらの移行形のものが認めら れた．特汇細胞の基底部てての顆粒は大きくその内容の 暗い部分之微細腺維が明瞭なものが多い。これらの内容 物加ら，乙れ注漏斗部の大型空胞之，蛋白分泌部の線維
状物質を内包する分泌物との移行的性格をもつものでは ないかと思われる。この他，非線毛細胞に杯細胞と乙て の微細構造定示するのがららた。 その分泌物は一様な 極微粒子で満をされていて，膨大部の杯細胞の分泌物が 示す樣な不規則な網状檴造は明らかでない，固有層に漏 斗部の腺に混在して蛋白分泌腺它すでに認めたが，雨者 の移行形は見当らなかった。この移行部はかつてカラザ 部といわれたが、後にそのことは否定された。

しかし以上の観察結果より，移行部は漏斗部と異なり 蛋白分泌部の分泌物之類似の物質它分泌する特徴ある機 能をむっもの上考学ら礼る。 


\section{MAKITA * KIWAKI}

\section{Explanation of Figures}

Fig. 1. A ciliated cell in the junctional area

It is similar to ciliated cell of the rest of the infundibulum as well as that of magnum in respects to the cilia (CIL), basal body (BB), lateral knob (LK), rootlets (RL), irregularly shaped microvilli (MVI), secretion granules (G), Golgi complex (GO), mitochondria (MT), tiny vesicles (VE), multi vesicular bodies (MV), free ribosomes (RI) and junctional complex (JC) including short desmosomes (D).

Fig. 2. A non-ciliated cell in the junctional area

The medium-sized dense granules $(G)$, short rough-surfaced endoplasmic reticulum (ER), vesicle containing vacuole (A) and tonofilaments (F) are conspicuous.

Fig. 3. The apical area of a non-ciliated cell

Note the globules that cotain some dense particles (arrows). Centriole (CE), ER and tonofilaments $(F)$ are also visible in this micrograph.

Fig. 4. The basal area of a non-ciliated cell

Suffice to the dense particles (arrows), some filamentous matrices (FIL) are seen in the globules. The particles and the filaments tend to be more remarkable: in the basal area than in the apical area of the cells. Both Golgi complex and rough-surfaced endoplasmic reticulum (ER) are not away from the globules. The close relationship between $E R$ and mitochondria is also appreciable.

Fig. 5. Another type of the non-ciliated cell specific to the transitional area

This is a kind of goblet cell of which supranuclear region is occupied with the secretions (SE).

Fig. 6. Details of the goblet cells in Fig. 5

The secretion contains fine grains and no network structure is seen in it. Golgi complex (GO), mitochondria (MT) and short ER are visible among the secretions.

Fig. 7. The gland cell found in the transitional area

It is quite similar to the magnum gland cell.

Fig. 8. The cells in a muscular layer

Note the remarkable evaginations of the cell walls (arrows) and the filamentous elements (FL) around the nucleus $(\mathrm{N})$. 


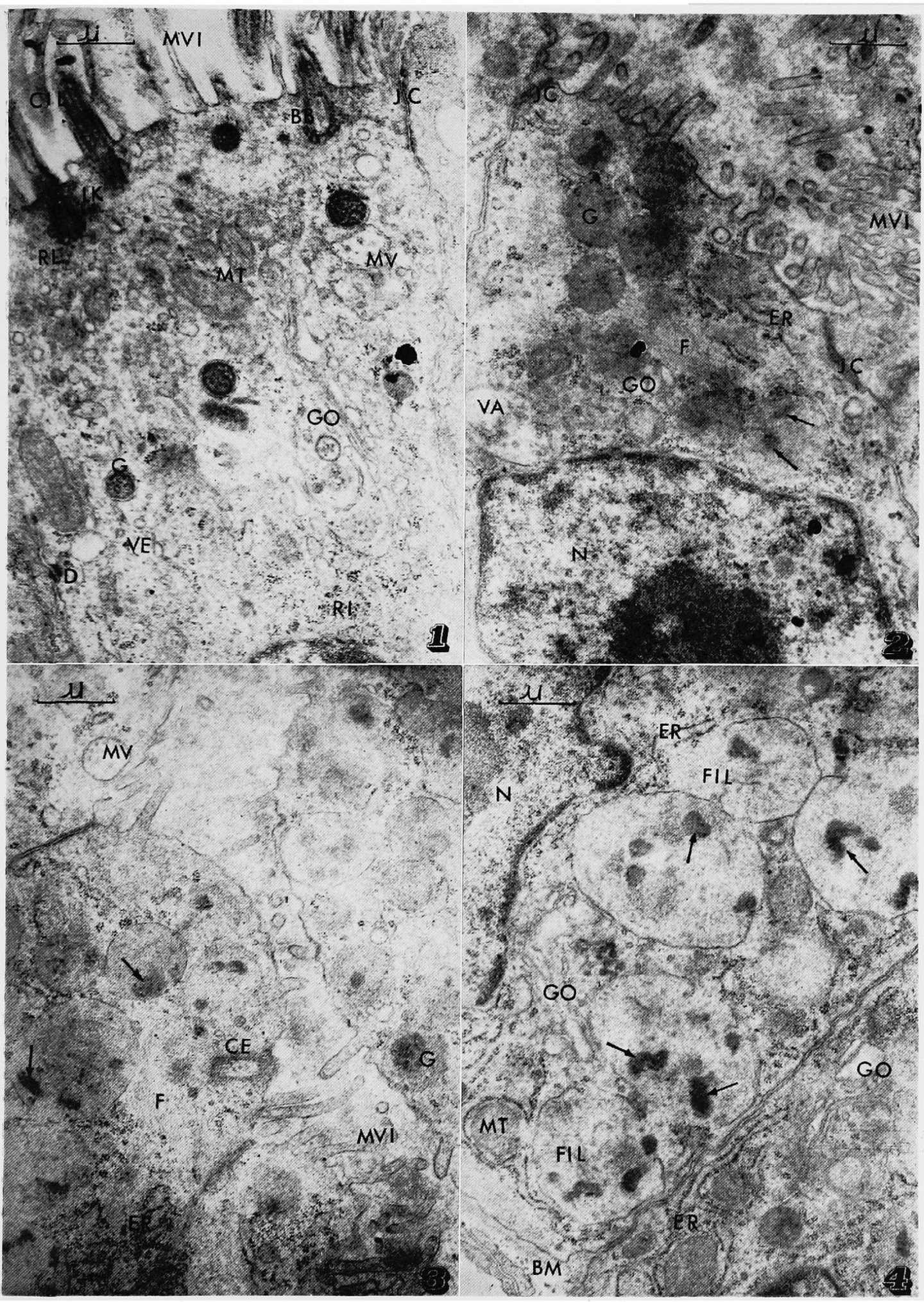



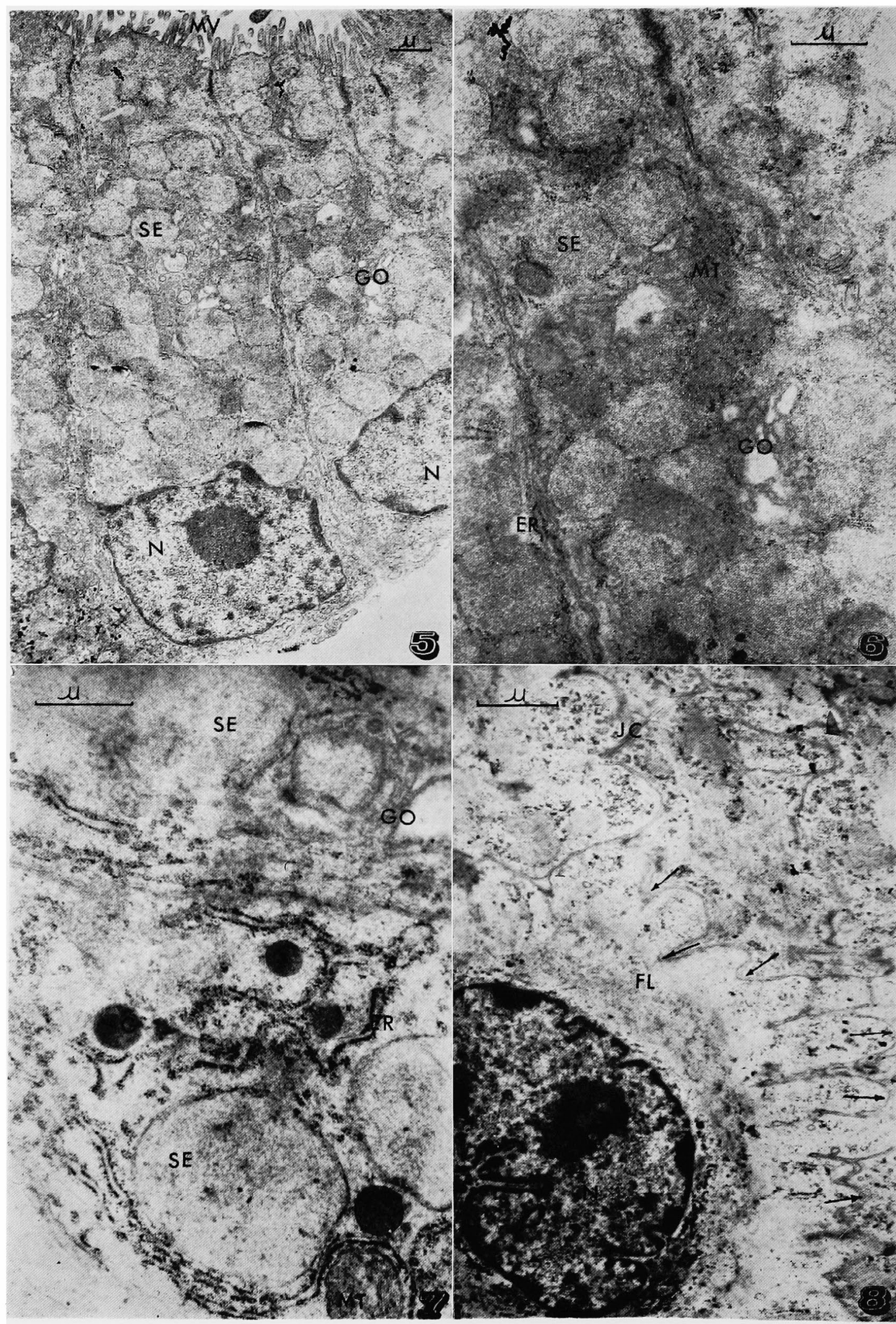

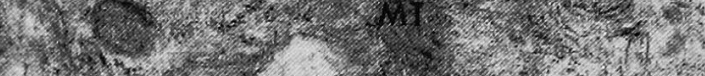

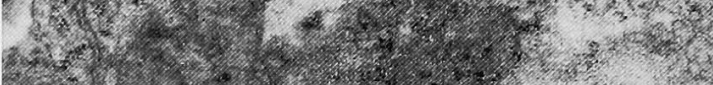

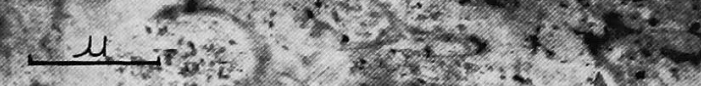

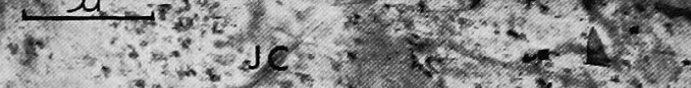

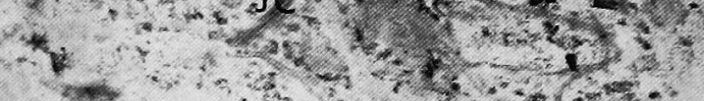

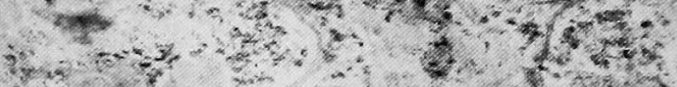

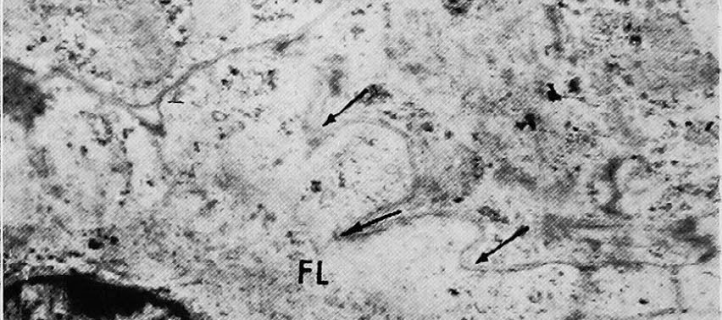

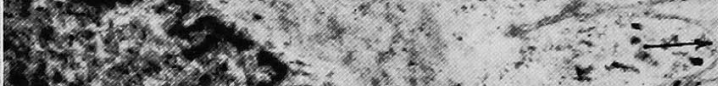

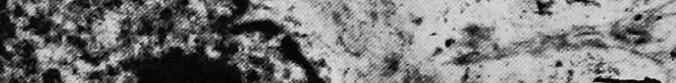

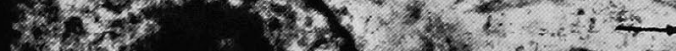

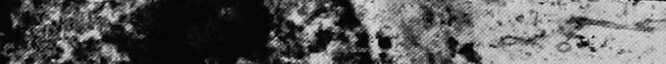
2.

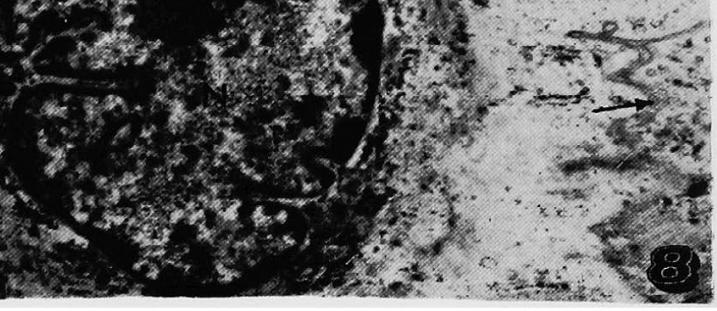

